\title{
Shell morphology and genetic characteristics of Corbula (Potamocorbula) spp. (Bivalvia: Corbulidae) from the waters adjacent to Japan, Korea and San Francisco Bay
}

\author{
Masato Owada $^{1, *}$, Yoshitaro Kasai ${ }^{2}$, Shin'ichi Sato ${ }^{3}$, Jae-Sang Hong ${ }^{4}$ \\ ${ }^{1}$ Department of Biological Sciences, Kanagawa University, 2946 Tsuchiya, Hiratsuka 259-1293, Japan \\ ${ }^{2}$ Department of Earth Sciences, Graduate School of Science, Tohoku University, 6-3 Aoba, Aramaki, Aoba-ku, \\ Sendai 980-8578, Japan \\ ${ }^{3}$ The Tohoku University Museum, 6-3 Aoba, Aramaki, Aoba-ku, Sendai 980-8578, Japan \\ ${ }^{4}$ Department of Oceanography, Inha University, Incheon 402-751, South Korea
}

\begin{abstract}
Corbula (Potamocorbula) spp. are natively distributed in the waters adjacent to Japan and Korea. These populations are distinguished by 6 morphological characteristics. However, they have high geographic variation, and it is quite difficult to distinguish among them. In the present study, we investigated the geographic distribution of the morphological and genetic characteristics of Corbula (Potamocorbula) spp. collected from the waters adjacent to Japan, Korea and San Francisco Bay, USA. Shell morphology was inferred through canonical discriminant analysis (CDA) of 8 shell characteristics, and genetic characteristics were analysed using the DNA sequences of mitochondrial cytochrome $c$ oxidase subunit 1 (CO1) and nuclear internal transcribed spacer 2 (ITS2) regions. The results of CDA showed that the samples from Ganghwa-do in western Korea could be clearly separated from those of all the other localities. The molecular phylogenetic tree and haplotype network that were constructed from the CO1 and ITS2 regions, respectively, did not show clear groupings among the collected samples, except for 1 group composed of samples from Ganghwa-do. In addition, no differences in CO1 amino acid sequences could be found among any of the samples examined, including the Ganghwa-do samples. These facts suggest that Corbula (Potamocorbula) spp. distributed in the waters adjacent to Japan and Korea were separated into 2 groups. However, these 2 groups were genetically closely related, and it seems appropriate to treat them as 2 distinct species. The classification of the subgenus Potamocorbula should be re-examined at the species level.
\end{abstract}

KEY WORDS: Mollusca $\cdot$ Bivalvia $\cdot$ Corbulidae $\cdot$ Potamocorbula $\cdot$ Phylogeography $\cdot$ Classification Mitochondrial cytochrome $c$ oxidase subunit $1 \cdot$ Nuclear internal transcribed spacer 2

Resale or republication not permitted without written consent of the publisher

\section{INTRODUCTION}

Populations of the Asian (overbite) clam, Corbula (Potamocorbula) amurensis Schrenck, 1861, in San Francisco Bay, USA, have markedly increased since 1986. They were introduced to the region through ballast waters from a cargo ship that had stopped in
East Asia (Carlton et al. 1990, Nichols et al. 1990). It is known that the waters adjacent to Japan and Korea in the Northwest Pacific are inhabited by at least 4 species of the subgenus Potamocorbula Habe, 1955. These species are distinguishable from each other by 6 morphological characteristics: shell size, shell outline, shell inflation, shell thickness, posterior 
margin and position of the umbo (Zhuang \& Cai 1983, Habe 1994, Horikoshi \& Okamoto 1994, Tsuchida \& Okamura 1997). However, Sato $(2002,2005)$ and Sato \& Kanazawa (2004) reported that there were high geographic variations in these morphological characteristics, making it challenging to distinguish among these species.

Corbula (Potamocorbula) amurensis is regarded as an invasive species in San Francisco Bay and may have a significant impact on the estuarine ecosystem of the bay (Carlton 1999, Coan 2002, Kimmerer 2002, Greene et al. 2011). In addition, fossil specimens of this species have been used as indicators of a cool climate or brackish water during reconstructions of the paleoenvironments of the Late Pleistocene and Holocene in Japan (Matsushima 1984, Habe 1994). However, these may not be accurate until the relationships between the geographic distribution and morphological characteristics of Corbula (Potamocorbula) spp. are fully understood at both population and species levels. To clarify the relationships among members of Corbula (Potamocorbula) spp., it will be necessary to investigate the morphological and genetic characteristics of populations from various localities. There have been several discussions of the genetic characteristics of Corbula (Potamocorbula) spp. For example, Duda (1994) reported that C. (P.) amurensis from San Francisco Bay, California, shows high genetic variation. Further, Smith et al. (2012) indicated that $C$. (P.) amurensis from San Francisco Bay and the Ariake Sea, western Japan, can be identified using the same genetic marker, $18 \mathrm{~S}$ ribosomal
DNA. However, they did not simultaneously discuss the relationships between the morphological and genetic characteristics. In the present study, we investigated the geographic distribution of the morphological and genetic characteristics of the populations from the waters adjacent to Japan, Korea and San Francisco Bay through canonical discriminant analysis (CDA) of 8 shell characteristics and through the DNA sequences of mitochondrial cytochrome $C$ oxidase subunit 1 (CO1) and nuclear internal transcribed spacer 2 (ITS2) regions.

\section{MATERIALS AND METHODS}

\section{Sampling}

Corbula (Potamocorbula) spp. were collected from 8 localities shown in Fig. 1: Rokkaku River Estuary, Saga Prefecture, Ariake Sea, western Japan ( $\mathrm{N}=25$ individuals collected on 12 July 1998 and 23 November 2008); Dong River Estuary, Suncheon-si, southern Korea ( $\mathrm{N}=30,20$ August 2011); Mangyeong River Estuary, Gunsan-si, western Korea ( $\mathrm{N}=30,3$ May 2000 and 11 July 2008); Ganghwa-do, intertidal muddy sand flat, western Korea ( $\mathrm{N}=30,8$ May 1998 and 18 August 2011); Maeho Lake, Yangyang-gun, eastern Korea ( $\mathrm{N}=30$, 16 July 2008); Hinuma Lake, Ibaraki Prefecture, central Japan $(\mathrm{N}=30,31$ May 1998 and 30 July 2011); Obuchi Swamp, Aomori Prefecture, northern Japan $(\mathrm{N}=46,3$ September 1998 and 27 July 2009); and San Francisco Bay, California,
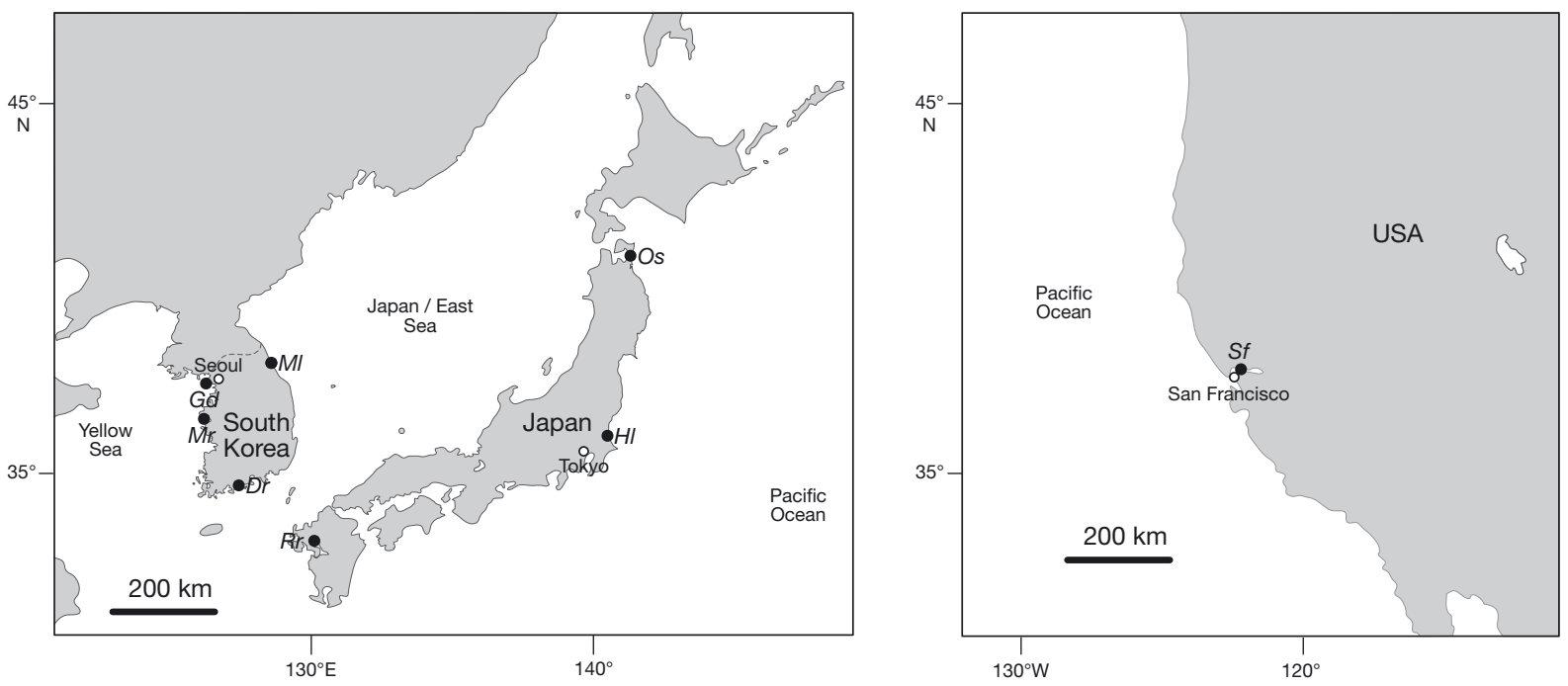

Fig. 1. Localities where the samples were collected. $R r$ : Rokkaku River Estuary $\left(33^{\circ} 11^{\prime} \mathrm{N}, 130^{\circ} 12^{\prime}\right.$ E); Dr: Dong River Estuary

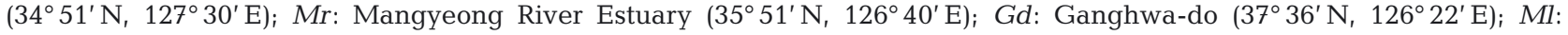
Maeho Lake $\left(37^{\circ} 56^{\prime} \mathrm{N}, 128^{\circ} 46^{\prime} \mathrm{E}\right)$; Hl: Hinuma Lake $\left(36^{\circ} 16^{\prime} \mathrm{N}, 140^{\circ} 30^{\prime} \mathrm{E}\right)$; Os: Obuchi Swamp $\left(40^{\circ} 57^{\prime} \mathrm{N}\right.$, $\left.141^{\circ} 22^{\prime} \mathrm{E}\right)$; Sf: San Francisco Bay $\left(37^{\circ} 27^{\prime} \mathrm{N}, 122^{\circ} 1^{\prime} \mathrm{W}\right)$ 
USA ( $N=30,9$ February 2000 and 9 November 2010). In addition, $C$. (P.) fasciata and Solidicorbula erythrodon, which were used as outgroups in the analysis of genetic variation, were collected from Bohol Island in the Philippines $\left(9^{\circ} 44^{\prime} \mathrm{N}, 123^{\circ} 53^{\prime} \mathrm{E}\right)$ on 8 June 2007 and from Sagami Bay in Japan $\left(35^{\circ} 17^{\prime} \mathrm{N}\right.$, $139^{\circ} 20^{\prime}$ E) on 7 September 2011, respectively. The soft tissue of living animals was preserved in $100 \%$ ethanol, and DNA was extracted from the foot or adductor muscle using the DNeasy Blood \& Tissue Kit (Qiagen). The shell and soft tissue were numbered in each individual. All voucher samples were deposited in the Tohoku University Museum (TUMC Nos. 111200 to 111207 ).

\section{Morphological analysis}

Eight shell characteristics (in $\mathrm{mm}$ ): shell length $(L)$, shell breadth $(B)$, shell height of left valve $(H L)$, shell height of right valve $(H R)$, thickness of shell margin $(T)$, height of umbo $(U)$, posterior shell length $(P L)$ and upper shell height $(U H)$ were measured on each individual (Fig. 2). For measurement of $L, H R, U, P L$ and $U H$, the outside of the right shell valve was photographed with a digital camera, and then each characteristic was measured using image analysis software, ImageJ ver. $1.45 \mathrm{~s}$. Further, $L, B$, $H L, H R$ and $T$ were measured using a digital slide caliper (accuracy $\pm 0.01 \mathrm{~mm}$ ). $L$ and $H R$ were measured using both methods, but there were no significant differences $(p>0.05)$ between them. Then, to standardize the variability for size, all characteristics were log-transformed (using base 10 logs), and the 7 characteristics excluding $L$ were divided by the $\log L$. CDA was tested with the standardized 7 characteristics using SPSS (Ver. 16.0).
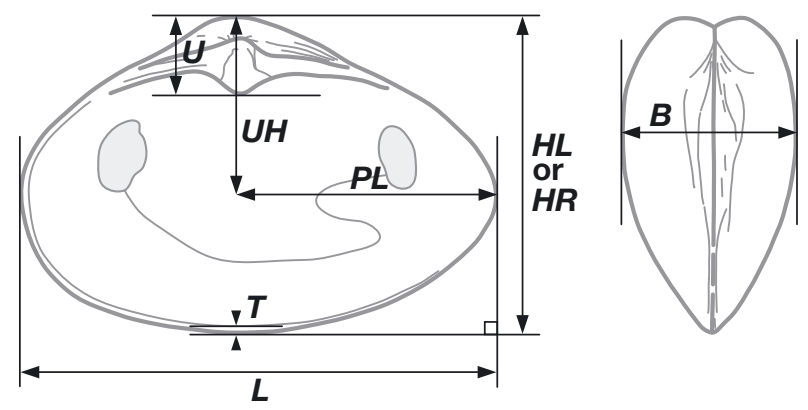

Fig. 2. Corbula (Potamocorbula) spp. Eight characteristics of left and right shell valves and shell breadths measured on shells. $L$ : shell length; $B$ : shell breadth; $H L$ : shell height of left valve; $H R$ : shell height of right valve; $T$ : thickness of shell margin; $U$ : height of umbo; $P L$ : posterior shell length; $U H$ : upper shell height

\section{Polymerase chain reaction (PCR)}

CO1 and ITS2 regions were amplified using Premix Taq (Takara) and a PCR Thermal Cycler PERSONAL (Takara). The following primers were newly designed for the present study: 5'-TCW ACA AAT CAY AAA GAT ATT GG-3' (forward) and 5'-ACY TCM GGR TGM CCA AAA AAT CA-3' (reverse) for the CO1 region, and 5'-ATT GCA GGA CAC ATT GAA CAT CG-3' (forward) and 5'-GTT ACT GAG GGA ATC CTT GTT A-3' (reverse) for the ITS2 region. The conditions for PCR amplification were as follows: denaturation at $94^{\circ} \mathrm{C}$ for $30 \mathrm{~s}$, annealing at $54^{\circ} \mathrm{C}$ for $30 \mathrm{~s}(\mathrm{CO} 1)$ and $55^{\circ} \mathrm{C}$ for $30 \mathrm{~s}$ (ITS2) and extension at $72^{\circ} \mathrm{C}$ for $60 \mathrm{~s}$. These steps were repeated 30 times. The PCR products were purified using ExoSAP-IT (USB), and cycle-sequencing reactions were performed using BigDye Terminator Version 3.1 Cycle Sequencing Kit (ABI PRISM). The sequences were compiled using a 3130 Genetic Analyzer (ABI PRISM) from both the $5^{\prime}$ and $3^{\prime}$ directions. These sequences were registered in the DNA Data Bank of Japan (CO1: AB740093 to AB740137 and AB827932 to AB827935, ITS2: AB740177 to AB740218 and AB827936 to AB827938).

\section{Genetic analysis}

In the analysis of genetic variation in the CO1 region, the sequences of Varicorbula dissimilis (AF 120669), Solidicorbula erythrodon (AB740137), and Corbula (Potamocorbula) fasciata (AB740136) were included as outgroups. After alignment using Clustal W Version 1.8 (Thompson et al. 1997), sites that contained gaps or those that could not be confirmed by homology were removed from the analysis. A molecular phylogenetic tree was reconstructed using maximum-likelihood (ML) and Bayesian methods, respectively. The ML method was performed by PAUP Version $4.0^{*}$ b10 (Swofford 2002). The tree search algorithm was a likelihood ratchet algorithm (2000 times) (Vos 2003), and the model for the ML method was selected using Modeltest Version 3.7 (Posada \& Crandall 1998). A bootstrap test was conducted 1000 times. The Bayesian method was performed by MrBayes Version 3.1.2 (Ronquist \& Huelsenbeck 2003). This program was run for 5000000 generations, with sampling every 1000th generation. The model for the Bayesian method was determined using Mrmodeltest Version 2.3 (Posada \& Buckley 2004).

In the analysis of genetic variation in the ITS2 region, the sequences were aligned using Clustal W 
Version 1.8 (Thompson et al. 1997). Sites that contained gaps and those that could not be confirmed by homology were removed from the analysis. Further, a haplotype network was built using TCS Version 1.21 (Clement et al. 2000).

\section{RESULTS}

\section{Canonical discriminant analysis}

Shells of representative individuals collected from each locality are shown in Fig. 3. According to the results of CDA, individuals from Ganghwa-do can be clearly separated from those of all the other localities by the 7 standard morphological characteristics (Fig. 4). The proportions of Canonical Variates 1 and 2 were 84.6 and $8.3 \%$, respectively (Table 1). The centroid of Canonical Variate 1 in individuals from Ganghwa-do was less than -6 , but those from the other 7 localities were all more than -2 . The shell characteristics that largely affect Canonical Variate 1 were shell height and height of umbo (Table 2). Namely, individuals from Ganghwa-do have smaller shell heights and umbos rather than those from the other 7 localities (Fig. 3).

The other 7 samples beside Ganghwa-do cannot be clearly separated from each other (Fig. 4). However, individuals from Maeho Lake and Hinuma Lake have similar shell morphology, and those from Rokkaku River Estuary, Mangyeong River Estuary and San Francisco Bay were also of similar shell shape (Fig. 4). The samples from Dong River Estuary and Obuchi Swamp were slightly different from the other 5 samples, but some individuals overlapped morphologically (Fig. 4). In conclusion, though these 7 samples have a characteristic shell morphology, they cannot be distinguished because of the high morphological variability.

Among the samples from each locality, the percent of correct cases in multivariate discriminant analysis ranged between 100 and $60.0 \%$ (Table 3). All indi-

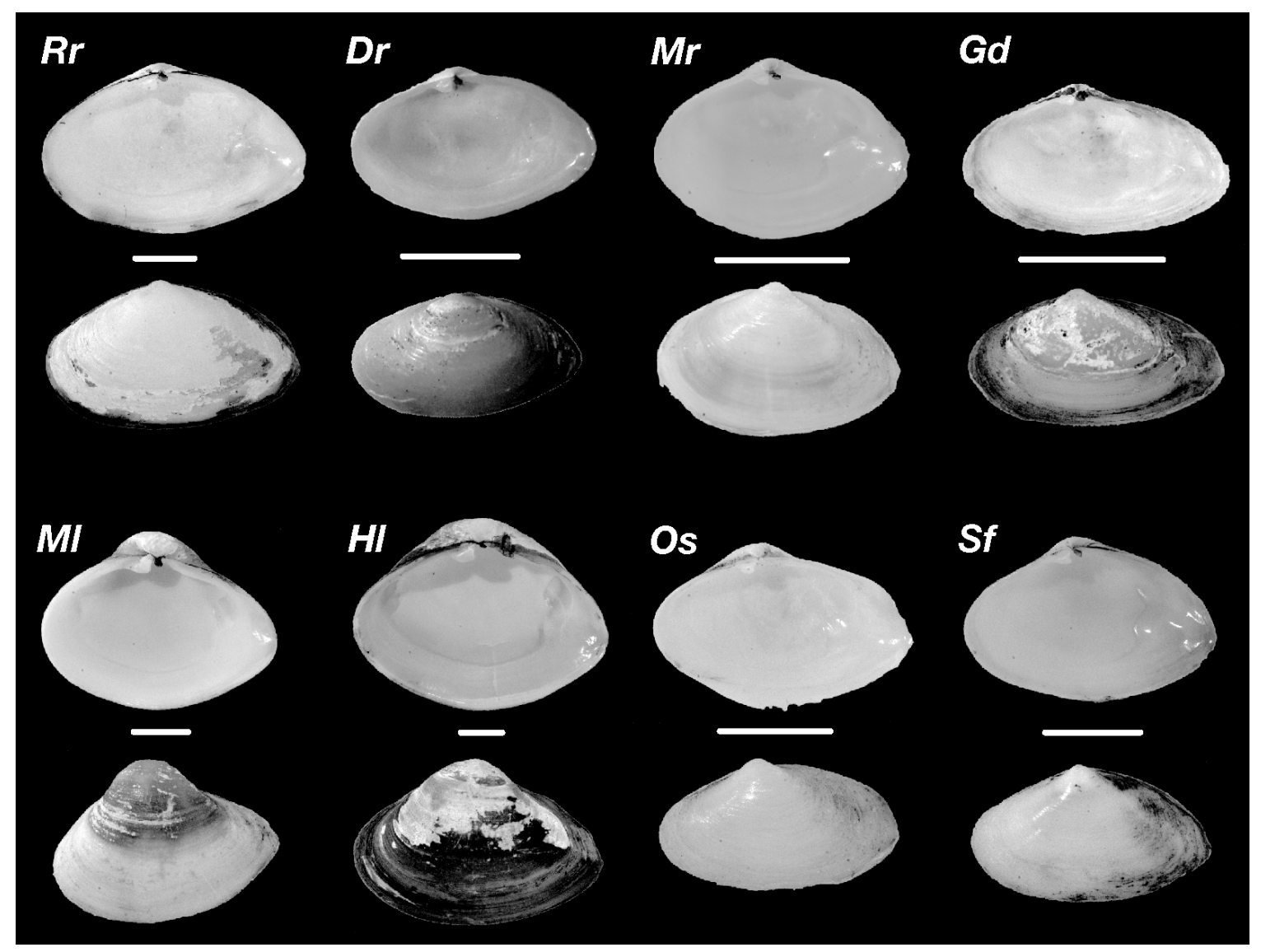

Fig. 3. Corbula (Potamocorbula) spp. Representative individuals collected from each locality. For each locality the upper 2 rows display the right valve and the lower 2 rows display the left valve. Scale bars: $5 \mathrm{~mm}$. Rr: Rokkaku River Estuary; Dr: Dong River Estuary; Mr: Mangyeong River Estuary; Gd: Ganghwa-do; Ml: Maeho Lake; Hl: Hinuma Lake; Os: Obuchi Swamp; Sf: San Francisco Bay 


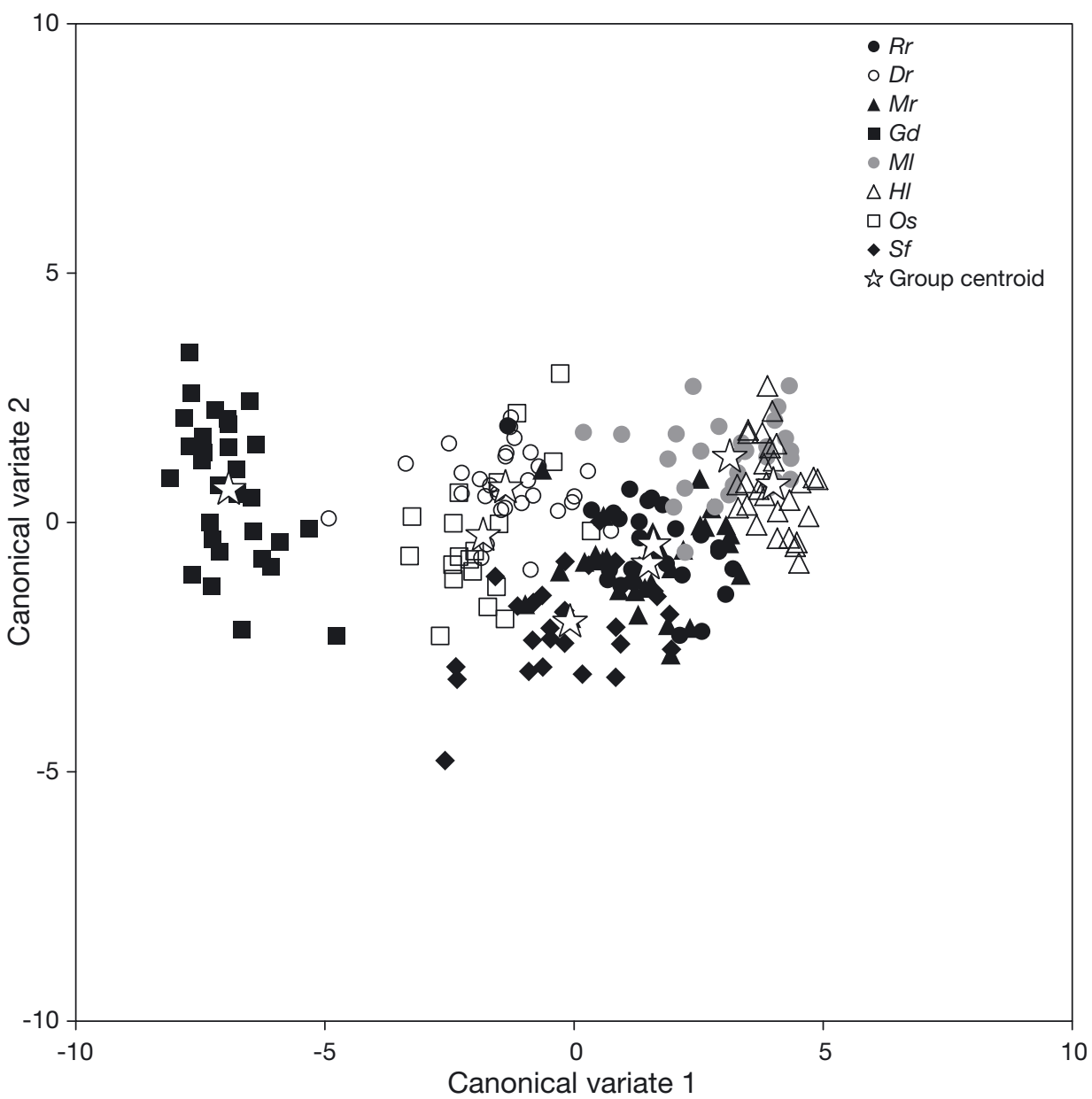

Fig. 4. Corbula (Potamocorbula) spp. Two-dimensional scattergrams of Corbula (Potamocorbula) spp. from 8 localities obtained with canonical discriminant analysis. The values of Canonical Variates 1 and 2 for each individual and the centroids for individuals from each locality are shown. Rr: Rokkaku River Estuary; Dr: Dong River Estuary; Mr: Mangyeong River Estuary;

Gd: Ganghwa-do; Ml: Maeho Lake; HI: Hinuma Lake; Os: Obuchi Swamp; Sf: San Francisco Bay

Table 1. Corbula (Potamocorbula) spp. Standardized coefficients of 7 characteristics, eigenvalue and proportion of Canonical Variates 1 and 2 for 8 groups. L: shell length; $B$ : shell breadth; $H L$ : shell height of left valve; $H R$ : shell height of right valve; $T$ : thickness of shell margin; $U$ : height of umbo; $P L$ : posterior shell length; $U H$ : upper shell height

\begin{tabular}{|lcc|}
\hline Characteristics & \multicolumn{2}{c|}{$\begin{array}{c}\text { Standardized coefficients of } \\
\text { Canonical Variates: } \\
\end{array}$} \\
& 1 & 2 \\
\hline $\log B / \log L$ & -0.248 & 1.115 \\
$\log H L / \log L$ & 0.385 & 0.255 \\
$\log H R / \log L$ & 0.361 & -0.475 \\
$\log T / \log L$ & 0.357 & -0.199 \\
$\log U / \log L$ & 0.451 & 0.226 \\
$\log P L / \log L$ & -0.200 & 0.227 \\
$\log U H / \log L$ & 0.095 & -0.853 \\
Eigenvalue & 11.314 & 1.108 \\
Proportion & 84.6 & 8.3 \\
\hline
\end{tabular}

Table 2. Corbula (Potamocorbula) spp. Centroids of Canonical Variates 1 and 2 for individuals from 8 localities. $R r$ : Rokkaku River Estuary; Dr: Dong River Estuary; Mr: Mangyeong River Estuary; Gd: Ganghwa-do; Ml: Maeho Lake; Hl: Hinuma Lake; Os: Obuchi Swamp; Sf: San Francisco Bay

\begin{tabular}{|lcc|}
\hline \multirow{2}{*}{ Locality } & \multicolumn{3}{c|}{ Centroid of Canonical Variate: } \\
& 1 & 2 \\
\hline$R r$ & 1.589 & -0.440 \\
$D r$ & -1.377 & 0.702 \\
$M r$ & 1.496 & -0.809 \\
$G d$ & -6.914 & 0.651 \\
$M l$ & 3.127 & 1.317 \\
$H l$ & 4.008 & 0.752 \\
$O s$ & -1.822 & -0.258 \\
$S f$ & -0.077 & -1.980 \\
\hline
\end{tabular}


Table 3. Corbula (Potamocorbula) spp. Discrimination scores using multivariate discriminant analysis among individuals from 8 localities. Rr: Rokkaku River Estuary; Dr: Dong River Estuary; Mr: Mangyeong River Estuary; Gd: Ganghwa-do; Ml: Maeho Lake; Hl: Hinuma Lake; Os: Obuchi Swamp; Sf: San Francisco Bay

\begin{tabular}{|c|c|c|c|c|c|c|c|c|c|c|c|}
\hline & \multirow{2}{*}{$\begin{array}{c}\text { No. of } \\
\text { total cases }\end{array}$} & \multirow{2}{*}{$\begin{array}{c}\text { No. of } \\
\text { correct cases }\end{array}$} & \multirow{2}{*}{$\begin{array}{c}\text { Percent of } \\
\text { correct cases }\end{array}$} & \multicolumn{8}{|c|}{ Number of classified cases } \\
\hline & & & & $R r$ & $D r$ & $M r$ & $G d$ & $M l$ & $H l$ & Os & $S f$ \\
\hline$R r$ & 25 & 19 & 76.0 & 19 & 1 & 5 & 0 & 0 & 0 & 0 & 0 \\
\hline$D r$ & 30 & 27 & 90.0 & 0 & 27 & 2 & 1 & 0 & 0 & 0 & 0 \\
\hline$M r$ & 30 & 18 & 60.0 & 6 & 1 & 18 & 0 & 1 & 1 & 0 & 3 \\
\hline$G d$ & 30 & 30 & 100.0 & 0 & 0 & 0 & 30 & 0 & 0 & 0 & 0 \\
\hline$M l$ & 29 & 22 & 75.9 & 1 & 1 & 1 & 0 & 22 & 4 & 0 & 0 \\
\hline $\mathrm{Hl}$ & 28 & 24 & 85.7 & 0 & 0 & 0 & 0 & 4 & 24 & 0 & 0 \\
\hline Os & 20 & 19 & 95.0 & 0 & 1 & 0 & 0 & 0 & 0 & 19 & 0 \\
\hline$S f$ & 30 & 20 & 66.7 & 1 & 0 & 8 & 0 & 0 & 0 & 1 & 20 \\
\hline Total & 222 & 179 & 80.6 & 27 & 31 & 34 & 31 & 27 & 29 & 20 & 23 \\
\hline
\end{tabular}

viduals from Ganghwa-do were classified correctly, but $25.0 \%$ of the individuals from the other 7 localities were classified incorrectly (43 out of 172 ind.) (Table 3 ).

\section{Genetic variation of the CO1 region}

DNA sequences of $606 \mathrm{bp}$ in length were compiled for 47 individuals. They were 5 sequences from Rokkaku River Estuary, 4 from Dong River Estuary, 8 from Mangyeong River Estuary, 8 from Ganghwa-do, 3 from Maeho Lake, 4 from Hinuma Lake, 8 from Obuchi Swamp and 7 from San Francisco Bay. After the alignment, a 594 bp sequence was used for the genetic analysis. Genetic variation among the sequences was found at 64 nucleotide sites $(11 \%)$; however, the sequences of some individuals were identical. The sequences that were translated to amino acids were the same in all the individuals from the 8 localities. There were 25 amino acid substitutions between the ingroup and the outgroup Corbula (Potamocorbula) fasciata.

In the ML method, the K81uf+G model was selected by Modeltest Version 3.7 and the likelihood index $(-\ln L)$ was 2593.56183. In the Bayesian method, the GTR+G model was selected by Mrmodeltest. A strict consensus tree was computed from these 2 trees (Fig. 5). In the strict consensus tree, all individuals from the 8 localities formed a monophyletic group and Corbula (Potamocorbula) fasciata was identified as a sister group of the monophyletic group. The individuals from

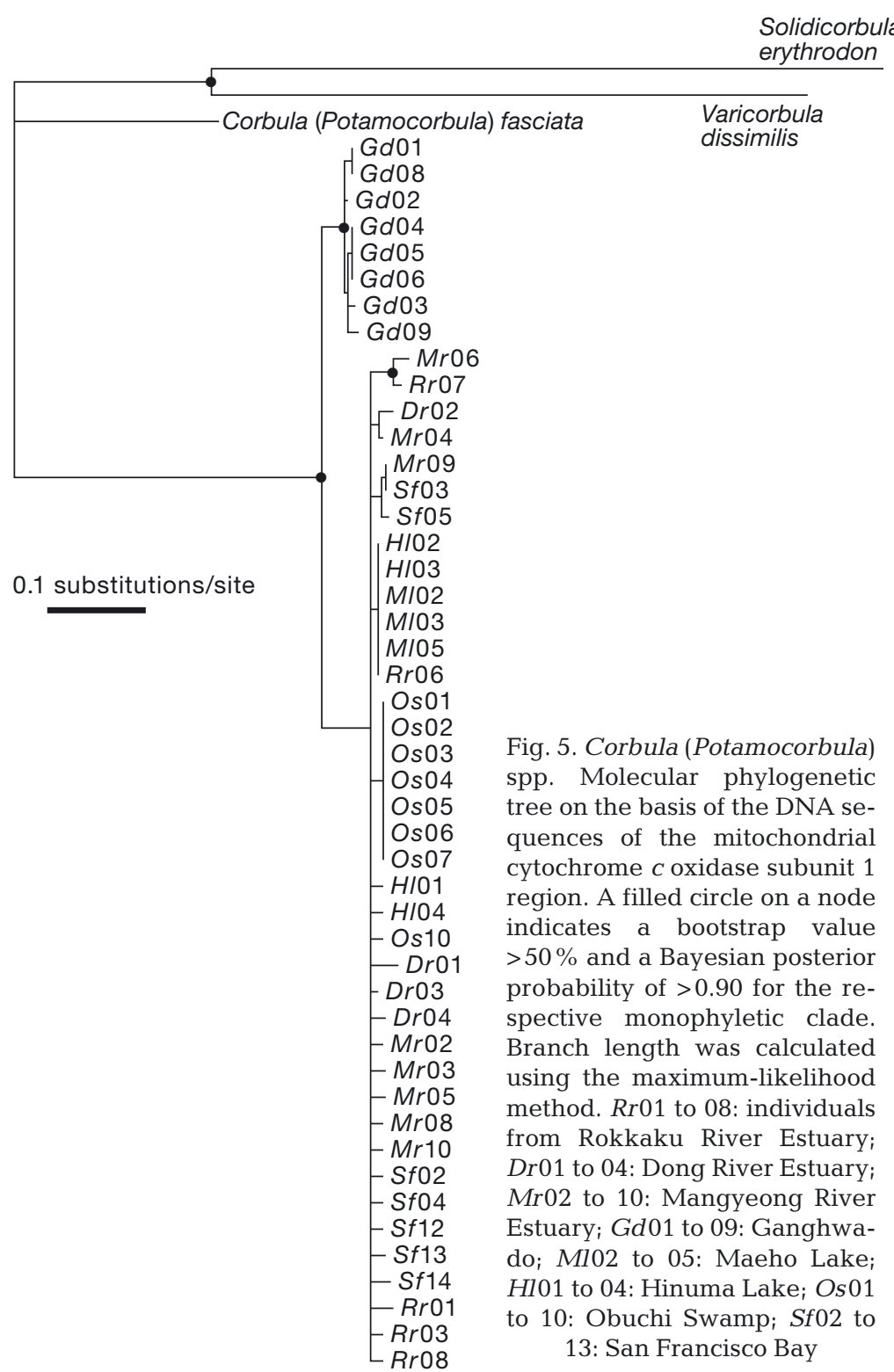


Ganghwa-do formed a monophyletic group, and it was a sister group of the other 7 localities. Some individuals from Rokkaku River Estuary, Mangyeong River Estuary and San Francisco Bay formed monophyletic groups (Fig. 5).

\section{Genetic variation of the ITS2 region}

Sequences of 384 to $393 \mathrm{bp}$ in length were compiled for 45 individuals. They were 5 sequences from Rokkaku River Estuary, 3 from Dong River Estuary, 8 from Mangyeong River Estuary, 8 from Ganghwa-do, 4 from Maeho Lake, 4 from Hinuma Lake, 6 from Obuchi Swamp and 7 from San Francisco Bay. After the alignment, a 377 bp sequence was used for genetic analysis. Genetic variation among the sequences was found at 16 sites (4\%).

The haplotype network is shown in Fig. 6, and it revealed 10 unique haplotypes forming 2 groups. The highest divergence among them was $11 \mathrm{bp}$. One group included only individuals from Ganghwa-do, and the other group was composed of the remaining individuals. In the Ganghwa-do group, 3 haplotypes were identified, and the highest divergence was $3 \mathrm{bp}$. In the group containing all the other individuals, 7 haplotypes were identified, and the highest divergence was $4 \mathrm{bp}$. One haplotype was found in the samples from 6 investigated localities, except for those from Dong River Estuary and Ganghwa-do (Fig. 6).

\section{DISCUSSION}

According to the criteria of Zhuang \& Cai (1983), the samples from Rokkaku River Estuary, Mangyeong River Estuary and San Francisco Bay were identified as Corbula (Potamocorbula) amurensis, those from Ganghwa-do as a morphological type of C. (P.) laevis Hinds, 1843, those from Maeho Lake and Hinuma Lake as C. (P.) ustulata (Reeve 1844) and those from Dong River Estuary and Obuchi Swamp as C. (P.) rubromuscula (Zhuang \& Cai 1983). However, Horikoshi \& Okamoto (1994) identified the samples from Rokkaku River Estuary as C. (P.) cf. laevis. Tsuchida \& Okamura (1997) identified the

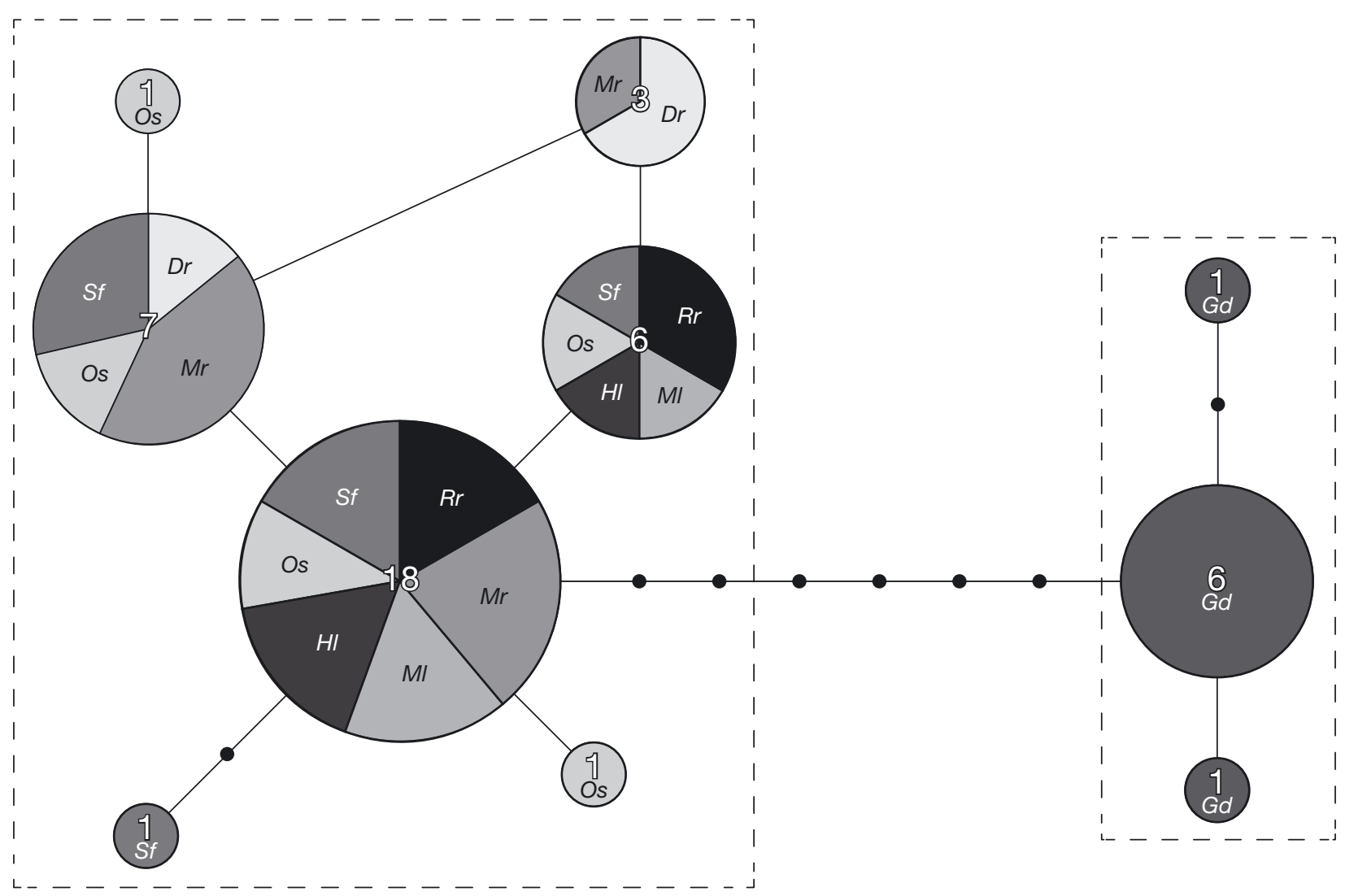

Fig. 6. Corbula (Potamocorbula) spp. Haplotype network on the basis of the DNA sequences of the nuclear internal transcribed spacer 2 region. Numerals indicate the number of individuals in the samples. Rr: Rokkaku River Estuary; Dr: Dong River Estuary; Mr: Mangyeong River Estuary; Gd: Ganghwa-do; Ml: Maeho Lake; Hl: Hinuma Lake; Os: Obuchi Swamp; Sf: 
samples from Hinuma Lake as C. (P.) ustulata, in agreement with Zhuang \& Cai (1983), though Huber (2010) defined this species as a junior synonym of C. (P.) nimbosa Hanley, 1843.

On the basis of their classification, Corbula (Potamocorbula) spp. distributed in the waters adjacent to Japan and Korea are divided into at least 4 species. If the classification is accurate, then these groups could be indicated through the analysis of morphological and molecular characteristics. However, the investigated samples did not form any species groups, except for the group composed of samples from Ganghwa-do. In the CDA results, samples from Ganghwa-do were clearly separated from those of the other 7 localities. Among the CO1 and ITS2 sequences, which were used to analyze intra-species relationships, the greatest difference was found between the groups composed of samples from Ganghwa-do and those composed of the remaining samples. This difference was larger than the largest difference among the samples from the other 7 localities. Therefore, the samples from Ganghwa-do can be distinguished from those of the other localities on the basis of both morphological and genetic characteristics. Furthermore, the samples from Ganghwado inhabited the intertidal zone of a muddy sand flat at an extremely high population density (maximum density $>150000$ ind. $\mathrm{m}^{-2}$ ). This habitat is quite different from those of the other samples, which mainly inhabited the subtidal zone of mud flats or sand coasts. Therefore, reproductive isolation may have occurred between the Ganghwa-do population and the populations from the other localities. On the other hand, no differences in CO1 amino acid sequences, which has been frequently applied as a criterion for differences between species, were identified among any of the investigated samples. This suggests that the reproductive isolation occurred relatively recently.

Although the populations of Dong River Estuary, Mangyeong River Estuary, Maeho Lake and Obuchi Swamp are native to these places, we found no population-specific substitutions in CO1 and ITS2 regions. Further, the geographical distance between these localities would make it difficult for the populations inhabiting them to exchange genes. Thus, it may be concluded that these populations originated from a common, historically large population. In contrast, it is known that the populations of Rokkaku River Estuary, Hinuma Lake and San Francisco Bay were artificially introduced from other localities (Carlton et al. 1990, Nichols et al. 1990, Horikoshi \& Okamoto 1994, Tsutsumi et al. 1997). Some indi- viduals from Mangyeong River Estuary and Rokkaku River Estuary formed a clade with those from San Francisco Bay in the phylogenetic tree, and the samples from all the investigated localities, except for those from Dong River Estuary and Ganghwa-do, contained the same haplotype in the haplotype network. These facts suggest that the artificially introduced populations also belonged to the same historically large population. Therefore, it may be that the historical population was naturally or artificially separated and that the populations of the 7 localities were recently formed. Further, the population of Ganghwa-do may have separated from the historical population earlier than those of the other localities.

Nichols et al. (1990) and Nicolini \& Penry (2000) reported that Corbula (Potamocorbula) amurensis is euryhaline and inhabits seawater with salinity ranging from 5 to $25 \%$. In addition, the populations of Rokkaku River Estuary, Mangyeong River Estuary and San Francisco Bay have been commonly shown to increase quickly after sudden environmental changes such as reclamation (Takayasu et al. 2000, Sato et al. 2001, Sato 2002, 2005, Sato \& Azuma 2002, Sato \& Kanazawa 2004). These facts could cause high variations in morphological characteristics. Although Corbula (Potamocorbula) spp. have been treated as indicators of a cool climate or brackish water in the past, the results of the present study do not support this. The smaller shells of the Ganghwa-do population might indicate a high population density, but it is not clear whether genetic or environmental factors caused the shell reduction. Therefore, Corbula (Potamocorbula) spp. may not be used as a paleoenvironmental indicator.

The present study showed that Corbula (Potamocorbula) spp. distributed in the waters adjacent to Japan and Korea are divided into 2 groups on the basis of morphological and genetic characteristics. The 2 groups are closely related genetically; however, reproductive isolation between them is possible. Hence, currently, it seems appropriate to treat them as at least 2 distinct species. The classification of the subgenus Potamocorbula should be reexamined at the species level.

Hallan \& Willan (2010) described 2 species of genus Lentidium from northern Australia. Lentidium conspicuously resembles the subgenus Potamocorbula in shell morphology. Thus, Lentidium and Potamocorbula could be closely related, but further information on both morphological and genetic characteristics is needed to investigate the relationship between the 2 genera (cf. Hallan et al. 2013). 
Acknowledgements. We deeply thank Emr. Prof. I. Hayami, Prof. K. Kanazawa and Prof. A. Hino (Kanagawa University) for their support of this study. We are indebted to Prof. T. Yamaguchi (Kanagawa University) and Prof. J. T. Carlton (Williams College) for valuable comments, to Dr. R. Nakashima (AIST) for fruitful discussions and to Drs T. Haga (JAMSTEC) and J. K. Thompson (U.S. Geological Survey) for donating the samples and providing valuable comments. We are also grateful to 2 anonymous reviewers for useful comments. We acknowledge the Japan/Korea Tidal-Flats Joint Survey Group for their help in collecting the samples. This work was supported by a Grant-in-Aids for Scientific Research from the Japan Society for the Promotion of Science (19650219 and 21500861 to S.S.) and a grant from the National Institute of Biological Resources, funded by the Ministry of Environment of the Republic of Korea (NIBR No. 2013-02-001).

\section{LITERATURE CITED}

Carlton JT (1999) Molluscan invasions in marine and estuarine communities. Malacologia 41:439-454

Carlton JT, Thompson JK, Schemel LE, Nichols FH (1990) Remarkable invasion of San Francisco Bay (California, USA) by the Asian clam Potamocorbula amurensis. I. Introduction and dispersal. Mar Ecol Prog Ser 66:81-94

Clement M, Posada D, Crandall K (2000) TCS: a computer program to estimate gene genealogies. Mol Ecol 9: $1657-1659$

Coan EV (2002) The eastern Pacific recent species of the Corbulidae (Bivalvia). Malacologia 44:47-105

Duda TF (1994) Genetic population structure of the recently introduced Asian clam, Potamocorbula amurensis, in San Francisco Bay. Mar Biol 119:235-241

Greene VE, Sullivan LJ, Thompson JK, Kimmerer WJ (2011) Grazing impact of the invasive clam Corbula amurensis on the microplankton assemblage of the northern San Francisco Estuary. Mar Ecol Prog Ser 431:183-193

Habe T (1994) Potamocorbula amurensis. In: Fisheries Agency (ed) Basic data of rare wild aquatic organisms in Japan. I. Japan Fisheries Resource Conservation Association, Tokyo, p 79-80 (in Japanese)

Hallan A, Willan R (2010) Two new species of Lentidium (Myida: Corbulidae) from tropical northern Australia: remarkable fresh/fluviatile to brackish-water bivalves. Molluscan Res 31:143-153

Hallan A, Colgan DJ, Anderson LC, García A, Chivas AR (2013) A single origin for the limnetic-euryhaline taxa in the Corbulidae (Bivalvia). Zool Scr 42:278-287

Horikoshi M, Okamoto M (1994) An immigrant bivalve Potamocorbula cf. laevis (Hinds) recently propagated at the head of Ariake Bay, Kyushu, Japan. Chiribotan 24:77-83 (in Japanese)

Huber M (2010) Compendium of bivalves. ConchBooks, Hackenheim

Kimmerer WJ (2002) Effects of freshwater flow on abundance of estuarine organisms: physical effects or trophic linkages? Mar Ecol Prog Ser 243:39-55

Matsushima Y (1984) Shallow marine molluscan assemblages of postglacial period in the Japanese Islands - its historical and geographical changes induced by the environmental changes. Bull Kanagawa Prefect Mus 15: 37-109 (in Japanese with German and English abstract)

Nichols FH, Thompson JK, Schemel LE (1990) Remarkable invasion of San Francisco Bay (California, USA) by the Asian clam Potamocorbula amurensis. II. Displacement of a former community. Mar Ecol Prog Ser 66:95-101

Nicolini MH, Penry DL (2000) Spawning, fertilization, and larval development of Potamocorbula amurensis (Mollusca: Bivalvia) from San Francisco Bay, California. Pac Sci 54:377-388

Posada D, Buckley TR (2004) Model selection and model averaging in phylogenetics: advantages of the AIC and Bayesian approaches over likelihood ratio tests. Syst Biol 53:793-808

Posada D, Crandall KA (1998) Modeltest: testing the model of DNA substitution. Bioinformatics 14:817-818

Ronquist F, Huelsenbeck JP (2003) MrBayes 3: Bayesian phylogenetic inference under mixed models. Bioinformatics 19:1572-1574

Sato S (2002) Faunal response of bivalves and gastropods of large environmental disturbances caused by the construction of dyke for reclamation. Jpn J Benthol 57: 106-118 (in Japanese with English abstract)

Sato S (2005) Faunal response of bivalves to large environmental disturbances caused by huge reclamation projects in Japan and Korea - a comparison with the fossil bivalve assemblages. Aquabiology 159:356-361 (in Japanese)

Sato S, Azuma M (2002) Ecological and paleoecological implications of the rapid increase and decrease of an introduced bivalve Potamocorbula sp. after the construction of a reclamation dike in Isahaya Bay, western Kyushu, Japan. Palaeogeogr Palaeoclimatol Palaeoecol 185:369-378

Sato S, Kanazawa T (2004) Faunal change of bivalves in Ariake Sea after the construction of the dike for reclamation in Isahaya Bay, western Kyushu, Japan. Kaseki 76:90-99 (in Japanese with English abstract)

Sato S, Azuma M, Kondo H, Nishinokubi H (2001) Temporal changes of bivalves and gastropods in Isahaya Bay shut off from Ariake Sea, western Kyushu, Japan. Quat Res (Tokyo) 40:85-95 (in Japanese with English abstract)

Smith KF, Wood SA, Mountfort DO, Cary SC (2012) Development of a real-time PCR assay for the detection of the invasive clam, Corbula amurensis, in environmental samples. J Exp Mar Biol Ecol 412:52-57

Swofford DL (2002) PAUP*: phylogenetic analysis using parsimony (and other methods), Version 4.0b10. Sinauer Associates, Sunderland, MA

Takayasu K, Tanaka H, Sato S (2000) Paleoenvironmental meanings of the brackish-water clam Potamocorbula swarm beds in the sediment core SJ 96 from Lake Shinji, southwest Japan-in comparison with the occurrence in San Francisco Bay, California, USA. Geoscience Rept Shimane Univ 19:37-45 (in Japanese with English abstract)

> Thompson JD, Gibson TJ, Plewniak F, Jeanmougin F, Higgins DG (1997) The Clustal X windows interface: flexible strategies for multiple sequence alignment aided by quality analysis tools. Nucleic Acids Res 25:4876-4882

Tsuchida E, Okamura S (1997) Some commercial mollusks collected at Shanghai and Xiamen, China. Chiribotan 28: 39-44 (in Japanese)

Tsutsumi T, Nishimura K, Okamoto M (1997) Potamocorbula amurensis occurred at Hi-numa Swamp in Ibaraki Prefecture, eastern Japan. Chiribotan 28:11-12 (in Japanese)

> Vos RA (2003) Accelerated likelihood surface exploration: the likelihood ratchet. Syst Biol 52:368-373

Zhuang Q, Cai Y (1983) Studies on the Corbulidae (Bivalvia) off Chinese coasts. Trans Chinese Soc Malacol 1:57-68 (in Chinese with English abstract) 